\title{
The Protective Role of Silicon in Sugarcane Under Water Stress: Photosynthesis and Antioxidant Enzymes
}

\author{
Krishan K Verma ${ }^{1-3}$, Kai-Chao $\mathrm{Wu}^{1,2}$, Pratiksha Singh ${ }^{1-3}$, Mukesh Kumar Malviya ${ }^{1-3}$, Rajesh \\ Kumar Singh ${ }^{1-3}$, Xiu-Peng Song ${ }^{1,2}$ and Yang-Rui $\mathrm{Li}^{1,2 *}$ \\ ${ }^{1}$ Key Laboratory of Sugarcane Biotechnology and Genetic Improvement (Guangxi), Sugarcane Research Center of Chinese \\ Academy of Agricultural Sciences, China
}

${ }^{2}$ Guangxi Key Laboratory of Sugarcane Genetic Improvement, Sugarcane Research Institute, China

${ }^{3}$ Guangxi Key Laboratory of Crop Genetic Improvement and Biotechnology, China

*Corresponding author: Yang-Rui Li, Key Laboratory of Sugarcane Biotechnology and Genetic Improvement (Guangxi), Ministry of Agriculture, Sugarcane Research Center of Chinese Academy of Agricultural Sciences, Nanning, Guangxi - 530 007, China

\begin{abstract}
ARTICLE INFO

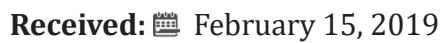

Published: 慧 February 28, 2019

Citation: Krishan K Verma, Kai-Chao Wu, Pratiksha Singh, Mukesh Kumar Malviya, Yang-Rui Li. The Protective Role of Silicon in Sugarcane Under Water Stress: Photosynthesis and Antioxidant Enzymes. Biomed J Sci \& Tech Res 15(2)-2019. BJSTR. MS.ID.002685.
\end{abstract}

Keywords: Biochemical; Gas Exchange; Photosynthetic Pigments; Silicon; Sugarcane; Water Deficit

\section{ABSTRACT}

To assess how silicon improves plant growth-development and productivity under water stress, we investigated the photosynthetic and biochemical activities of sugarcane cultivar GT 42 to Si application. Two water regimes [70 and $30 \%$ of soil available water content] and six silicon levels, i.e. 0, 20, 40, 60, 80 and 100g Si pot-1, respectively, were applied. This experiment was maintained in a completely randomized block design. The losses in photosynthetic and biochemical parameters due to water stress were alleviated by $\mathrm{Si}$ application. The Si application improves the plant growth and development under stress, accompanied with the up-regulated in photosynthesis ( 6-39 \& 2-93\%), stomatal conductance (14-43 \& 20-113\%), transpiration rate ( 19-40 \& 24-275\%), photosynthetic pigments such as Chl a ( 2-12 \& 3-25\%), Chl b ( 10-26 \& 12-35\%), Chl a+b (6-16 \& 2$28 \%$ ), relative water content ( $\sim 3-5 \& 4-8 \%)$ and biochemical activities, i.e. catalase (22$57 \& \sim 24-91 \%)$, peroxidase ( 8-31 \& 15-24\%) and superoxide dismutase ( $33-44 \& 47$ $96 \%)$. These results improved our understanding of the physio-biochemical mechanisms that underlie the silicon-induced enhances in sugarcane under water stress.

\section{Introduction}

Silicon ( $\mathrm{Si}$ ) is not considered as an essential plant nutrient element, and yet numerous scientific reports have shown its positive role in many plant species and environment circumstances Coskun et al. [1]. Silicon is an agriculturally important fertilizer that enhances plant tolerance to environmental stresses Hodson et al. [2]; Epstein et al. [3-7]. Silicon increased leaf transpiration rate and consequently mediated the loss of photosynthetic parameters by water stress in plants Sonobe et al. [7]. In past studies, antioxidant activities were activated by Si element during drought in maize Kaya et al. [8] and wheat Gong et al. [9,10]. Plants benefit from Si fertilization and uptake of various plant species is carried out as a standard method in agricultural and horticultural crop plants Ma et al. [11]; Guntzer [12].

In plants, silicon is alleviated a wide range of environmental stresses such as radiation Shen et al. [13], lodging Savant et al. [14], wounding Kim et al. [15], heat temperature Muneer et al. [16], hypoxia Fleck et al. [17], soil salinity Flam-Shepherd et al. [18], water deficit Liu et al. [19], nutritional imbalance, i.e. Fe (Pavlovic et al. [20]), P (Kostic et al. [21]) and K (Chen et al. [22]) and metal ion toxicity (cadmium - Shao et al. [23]; manganese - Che et al. [23]; arsenic - Sanglard et al. [24]; aluminum - Wang et al. [25] and Copper - Mateos-Naranjo et al. [26]. As a result of rapid global economic growth, water deficit is becoming an increasing serious environmental problem. At present, the pressure put on agricultural crop cultivation land has caused land degradation, a cultivation shift to large marginal areas and different soil types and qualities, and more requirements for the productivity of agricultural crops per unit area Glick [27]. In addition to undesirable responses on agro-environment ca. $70 \%$ of productivity loss in environmental stresses Veatch-Blohm [28].

Low soil water content is one of the common problems constraining crop production in over the world Dinh etal. [29], for ca. 
$30 \%$ of the global fertile agricultural land area. Severe water stress which restricts plant growth, development and photosynthetic characteristics Jangpromma et al. [30]; Graca et al. [31]; Barbosa et al. [32] is responsible for the loss in productivity Ramesh [33]; Zhao et al. [34]. The plants response to water deficit was observed in morphological changes, i.e. plant growth - development InmanBamber et al. [35]; Wilkinson et al. [36], and photosynthesis and plant water potential was also down-regulated. Sugarcane is considered as a renewable feedstock for economically important for sugar and bioenergy production Moore et al. [37-39]. Moreover, the remaining biomass used for the production of second-generation ethanol (2G-bioethanol) Dias et al. [40]; Pereira et al. [41]. The strength of sugarcane to produce high quantity of cane biomass and absorb maximum content of sucrose (ca. $700 \mathrm{mM}$ ) in the mature cane stalks Moore [42] are the result of a combination of different factors, including an efficient $\mathrm{C}_{4}$ crop that permits maximum yield of dry matter production hectare-1 Coombs [43].

This experiment investigated the role of Si application on photosynthetic and biochemical activities in sugarcane (cultivar GT 42) under water stress condition. The investigation aimed to understand the impacts of combined experiment with $\mathrm{Si}$ and water deficit and to provide evidence demonstrating the biological roles of silicon to tolerate water deficit.

\section{Materials and Methods}

\section{Plant Growth and Treatment}

This experiment was conducted in the greenhouse of Sugarcane Research Center, Nanning, Guangxi, China. Sugarcane (Saccharum spp. L.) plantlets of cultivar GT 42 was classified in the Sugarcane Research Center of Chinese Academy of Agricultural Sciences (CAAS) and Sugarcane Research Institute of Guangxi Academy of Agricultural Sciences (GXAAS), Nanning, Guangxi, China based on the morpho-physiological behavior and productivity in field experiments/ trials. Before planting, the bud sets were soaked in water for $48 \mathrm{~h}$ (Bavistin solution, $1 \mathrm{~g} \mathrm{~L}^{-1}$ water) for $5 \mathrm{~min}$. Fiftydays after culms germination, plantlets were transferred into the plastic pots (diameter $\sim 30 \mathrm{~cm}$; height $\sim 35 \mathrm{~cm}$ with a hole in the bottom) filled with $25 \mathrm{~kg}$ air-dried soil (clay soil/ organic manure/ sand, 70:20:10 w/w) with a basal dose of $\mathrm{N}, \mathrm{P}$ and $\mathrm{K}$ fertilizer ( $\mathrm{N}$ $26 \mathrm{~g}, \mathrm{P}-1.76 \mathrm{~g}$ and $\left.\mathrm{K}-20 \mathrm{~g} \mathrm{pot}^{-1}\right)$ and kept in greenhouse conditions. Urea (N-46.4\%), phosphate $\left(\mathrm{P}_{2} \mathrm{O}_{5}-12 \%\right)$ and potassium oxide $\left(\mathrm{K}_{2} \mathrm{O}\right.$ $60 \%$ ) fertilizer were used as a source of N, P and K, respectively. The substrate properties were analyzed before transplanting.

The soil pH was 5.92. Organic carbon $(0.72 \%)$ was measured through wet oxidation with potassium dichromate Nelson et al. [44]. Available phosphorus was $9.18 \mathrm{mg} \mathrm{kg}^{-1}$, based on the extraction of sodium bicarbonate solution Olsen et al. [45]. Soil available $\mathrm{K}, \mathrm{Ca}, \mathrm{Mg}$ and $\mathrm{Na}$ were 2.71, 4.0, 1.6 and $0.083 \mathrm{cmol}(+)$ $\mathrm{kg}^{-1}$ by ammonium acetate method Haby et al. [35]. Soil texture was sandy clay, according to hydrometer methods using $0.5 \%$ sodium hexametaphosphate solution Gee [27]. DTPA extractable $\mathrm{Cu}, \mathrm{Fe}$, Zn and Mn contents Lindsay et al. [46] were 0.85, 12.0, 1.31 and $18.8 \mathrm{mg} \mathrm{kg}^{-1}$, respectively. Sixty-days after trans-planting, thinning was performed and the three plants per pots were selected for the experiment on the basis of plant morphology. The experiment was arranged in completely randomized block design (CRBD) for the experiment, with four biological replicates of each treatment. All plantlets were irrigated daily upto field capacity to improve root development and growth before initiating treatments. During the experiment, all tillers were removed immediately after emergence.

Average soil available water content such as 75 and $30 \%$ of soil water was measured by using Soil Moisture Meter (TDZ), Top Instrument Co. Ltd. Zhejiang, China at $15 \mathrm{~cm}$ of soil depth. The climatic variables and soil water content (\%) were recorded inside the greenhouse during experiment (Figure 1). At 70-days after trans-planting, cultivar GT 42 was submitted to the stress situations (mild $-75 \%$ and severe - 30\% of SAWC) with different levels of silicon application. The average soil available moisture content (\%) in treated pots was maintained at $75 \pm 5$ and $30 \pm 5 \%$ during upto the end of the drying cycle (45-days). The experiments consisted of two-groups and six categories, i.e. T0-T5: 0, 20, 40, 60, 80 and 100g Si pot ${ }^{-1}$ (@25kg soil pot ${ }^{-1}$ ). Calcium metasilicate (CaO. $\mathrm{SiO}_{2}$ ), wollastonite powder was used as a source of Si that contains Si-24.18\%, 03-41.32\% and Ca-34.5\%. Si solution was applied two times at an interval of 15 days.

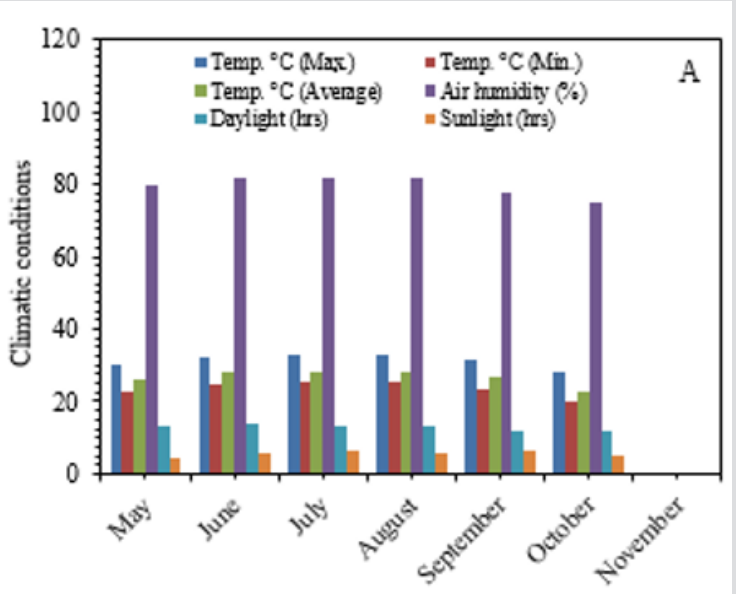

Normal plant growth and stress period

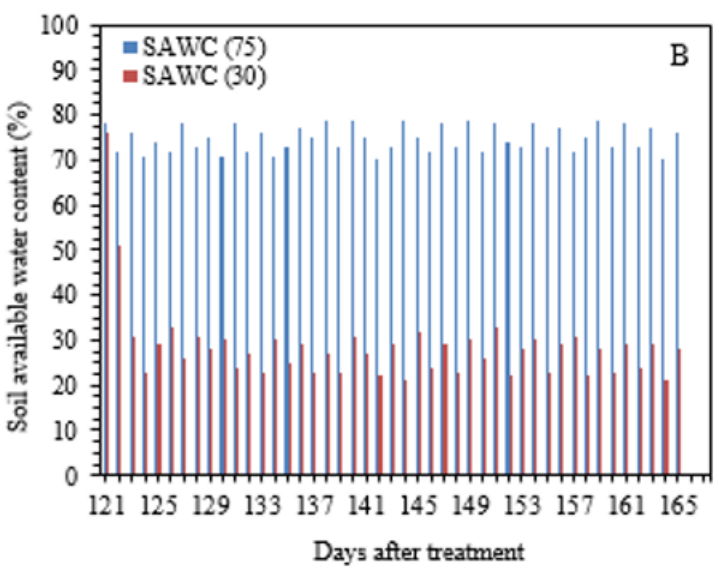

Figure 1: Air temperature $-{ }^{\circ} \mathrm{C}$ (minimum, average and maximum), average daylight and sunlight (hrs), air humidity (\%) and average soil available water content (SAWC, \%) during treatment (A and B) monitored inside the greenhouse. Soil available water content was monitored by Soil Moisture Meter (TZS), Top Instrument Co. Ltd., Zhejiang, China. 


\section{Photosynthetic Measurements}

Photosynthesis (PN), stomatal conductance (gs) and transpiration rate (E) were measured in the middle of leaf +1 (first completely expanded leaf that had a visible dewlap and was photosynthetically mature) using a Portable Photosynthetic System - LI-6800 (LI-COR Biosciences, Lincoln, Nebraska, USA). The $\mathrm{CO}_{2}$ value was fixed at $400 \mu \mathrm{mol} \mathrm{mol}-1$ by $\mathrm{CO}_{2}$ cylinder, light intensity at $1,000 \mu \mathrm{mol} \mathrm{m}^{-2} \mathrm{~s}^{-1}$ and leaf temperature at $25 \pm 1{ }^{\circ} \mathrm{C}$.

\section{Quantification of Green Pigments}

Chlorophyll a (Chl a), chlorophyll b ( $\mathrm{Chl} \mathrm{b}$ ) and total chlorophyll (Chl a+b) were assessed spectrophotometrically according to Strain et al. [47]. Fresh leaves ( $0.2 \mathrm{~g}$ ) were removed from the sugarcane plants and extracted with $10 \mathrm{ml}$ of $90 \%$ acetone $(\mathrm{v} / \mathrm{v})$. Absorbance were measured versus a blank of pure $90 \%$ acetone at wavelengths of 663 and $645 \mathrm{~nm}$ using an ultraviolet-visible spectrometer for chlorophyll a and b, respectively. Leaf relative water content (RWC\%) was measured according to Yamasaki et al. [48].

$$
\begin{aligned}
& \text { Chl a }\left(\mathrm{mg} \mathrm{L}^{-1}\right)=11.64 * \mathrm{~A} 663-2.16 * \mathrm{~A} 645 \\
& \mathrm{Chl} \mathrm{b}\left(\mathrm{mg} \mathrm{L}^{-1}\right)=20.97 * \mathrm{~A} 645-3.94 * \mathrm{~A} 663
\end{aligned}
$$

\section{Antioxidant Enzymes}

Fresh leaves $(0.5 \mathrm{~g})$ were frozen in liquid $\mathrm{N} 2$ and ground in 10 $\mathrm{mL}$ of $100 \mathrm{mM}$ potassium phosphate buffer (pH 7.0) containing $0.1 \mathrm{mM}$ Na2EDTA and $0.1 \mathrm{~g}$ of polyvinylpyrrolidone (PVP). The homogenate was then centrifuged at $15,000 * \mathrm{~g}$ for $10 \mathrm{~min}$ at $4^{\circ} \mathrm{C}$. Subsequently, the supernatant was stored at $4^{\circ} \mathrm{C}$ until being used for catalase, peroxidase and superoxide dismutase enzyme assays. The CAT (EC 1.11.1.6) activity was measured according to Aebi [49]. The decomposition of $\mathrm{H}_{2} \mathrm{O}_{2}$ was observed as the decline in absorbance at $240 \mathrm{~nm}$. In this activity, $50 \mathrm{mM}$ phosphate buffer $(\mathrm{pH}$ 7.8) and $10 \mathrm{mM} \mathrm{H}_{2} \mathrm{O}_{2}$ were used in the reaction solution. Peroxidase (EC 1.11.1.7) activity was quantified according to Maehly et al. [50] by assessing the oxidation rate of guaiacol in the presence of $\mathrm{H}_{2} \mathrm{O}_{2}$ at $470 \mathrm{~nm}$ Klapheck et al. [51]. The superoxide dismutase (EC 1.15.1.1) activity was observed based on the inhibition of nitroblue tetrazolium (NBT) photoinhibition according to Giannopolitis et al. [52]. The reaction mixture $(3 \mathrm{~mL})$ contained $50 \mu \mathrm{M}$ NBT, $1.3 \mu \mathrm{M}$ riboflavin, $13 \mathrm{mM}$ methionine, $75 \mathrm{nM}$ ethylenediamine tetraacetic acid (EDTA), $50 \mathrm{mM}$ phosphate buffer (pH 7.8) and $20-50 \mu \mathrm{L}$ of enzyme extract. The reaction mixture was irradiated under fluorescent light at $75 \mu \mathrm{M} \mathrm{m}^{-2} \mathrm{~s}^{-1}$ for $15 \mathrm{~min}$. One unit of SOD activity was defined as the amount of enzyme required to cause $50 \%$ inhibition of NBT photoreduction as monitored at $560 \mathrm{~nm}$.

\section{Statistical Analysis}

All data shown are the mean values. Data were statistically analyzed by the ANOVA with GraphPad Prism 8.0.1 Software, Inc. Data represented in the tables and figures are means of standard errors $( \pm)$ of quadruplicates independent replicates of each treatment.

\section{Results and Discussion}

Climatic conditions and average soil available water content (\%) were observed during the experiment as shown in Figure 1a-b. The air temperature and humidity ranging from $24.5-30.2^{\circ} \mathrm{C}$ and $73-80 \%$ were higher at $2.05 \pm 0.5^{\circ} \mathrm{C}$ and $7.3 \pm 2.0 \%$ than those outside of greenhouse, respectively.

\section{Physiological Parameters during Water Stress with Silicon}

The photosynthetic characteristics such as photosynthesis (PN), stomatal conductance (gs) and transpiration rate were significantly decreased during 70 and $30 \%$ of SAWC. Under the water deficit conditions, +Si showed a higher rate of PN [30.53 vs. $22.01(\sim 39 \%) \& 14.64$ vs. $7.60 \mu \mathrm{mol} \mathrm{CO} 2 \mathrm{~m}-2 \mathrm{~s}-1(\sim 15 \%)]$, gs [0.30 vs. $0.21(\sim 43 \%) \& 0.17$ vs. $0.08 \mathrm{~mol} \mathrm{H} 2 \mathrm{O} 2 \mathrm{~m}-2 \mathrm{~s}-1(\sim 113 \%)]$ and E [4.21 vs. $3.01(\sim 40 \%) \& 1.91$ vs. $0.51 \mathrm{mmol} \mathrm{m-2s-1} \mathrm{(} \mathrm{275 \% )]}$ at 45 days after treatment, than the -Si plants (Figure 2a-2c). The period and condition of the stress is also most important for plant development under drought stress conditions Passioura [53]. All plants require sufficient amount of essential mineral elements for plant growth and development. Silicon plays positive role in balancing the uptake, transport-distribution of minerals in drought stressed plants Zhu et al. [54,55]; Silicon has been proved to be beneficial for plant growth and development of various plant species Epstein et al. [56-60].
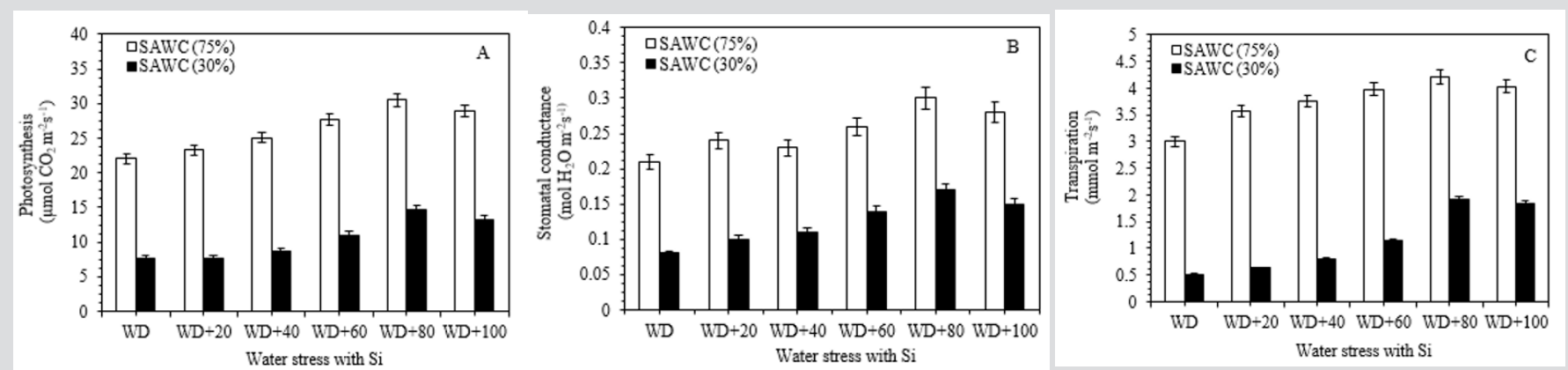

Figure 2: Ameliorating effect of silicon on the (A) photosynthesis (PN), (B) stomatal conductance (gs) and (C) transpiration rate (E) in the top visible dewlap (TVD) leaves of sugarcane cultivar GT 42 under 75 and 30\% of SAWC at 45 days after water stress with +Si. Observations were made by Portable LICOR - 6800 System (LI-COR Biosciences, Lincoln, Nebraska, USA). Each value represents the means $( \pm$ SEM) of at least 3-4 independent biological replicates. 
In fact, $\mathrm{P}_{\mathrm{N}}$, gs and $\mathrm{E}$ of $80-100 \mathrm{~g}$ Si for $25 \mathrm{~kg}$ soil pot ${ }^{-1}$ were significantly higher than those of $20-60 \mathrm{~g} \mathrm{Si}$, but not significant when plants under stressed conditions without $\mathrm{Si}$ fertilizer. Significant differences were found at 45 days after $+\mathrm{Si}$ as compare to stress without silicon (Figure 2). Photosynthetic observations are influenced by various environmental conditions, i.e. ambient $\mathrm{CO}_{2}$ level, light intensity, temperature and availability of water Bassi et al. [39]; Sage et al. [61-66] reported that photosynthesis of sugarcane has been related to plant age, and maturity of plants assimilated higher rates than older ones Passioura [67].

\section{Photosynthetic Pigments and Relative Water Content}

Chlorophyll is considered as an important parameter to verify the level of photosynthetic pigments involved in light absorption and energy transfer during the photochemical process of photosynthesis. Reduction in photosynthetic pigments may mark the start of stress. Results showed in Figure 3, that the decreasing SAWC, i.e. 70 and $30 \%$ in the soil was associated with progressive fall in green pigments biosynthesis and leaf relative water content in sugarcane leaves as compared to -Si with stress. The downregulation in chlorophyll may be due to the formation of proteolytic enzymes, i.e. chlorophyllase, which is responsible for pigment declining Sabater et al. [68] as well as damage to the photosynthetic apparatus Yasseen [69]; Kaya et al. [70]. On the other hand, the $\mathrm{WD}+80 \mathrm{~g}$ Si pot-1, increased the highest values of Chl a [1.48 vs. 1.32 (12\%) \& 0.45 vs. $0.36 \mathrm{mg} \mathrm{g-1FW} \mathrm{(25 \% )],} \mathrm{Chl} \mathrm{b} \mathrm{[0.53} \mathrm{vs.} 0.42(26 \%)$ \& 0.23 vs. $0.17 \mathrm{mg} \mathrm{g-1FW} \mathrm{(35 \% )],} \mathrm{Chl} \mathrm{(a+b)} \mathrm{[2.01} \mathrm{vs.} 1.74(\sim 15 \%)$ $\& 0.68$ vs. $0.53 \mathrm{mg}$ g-1FW (28\%)] and RWC [83 vs. 79 (5\%) \& 57 vs. $53(\sim 6 \%)]$ as compared with 75 and $30 \%$ of SAWC without silicon application (Figure 3a-3d).
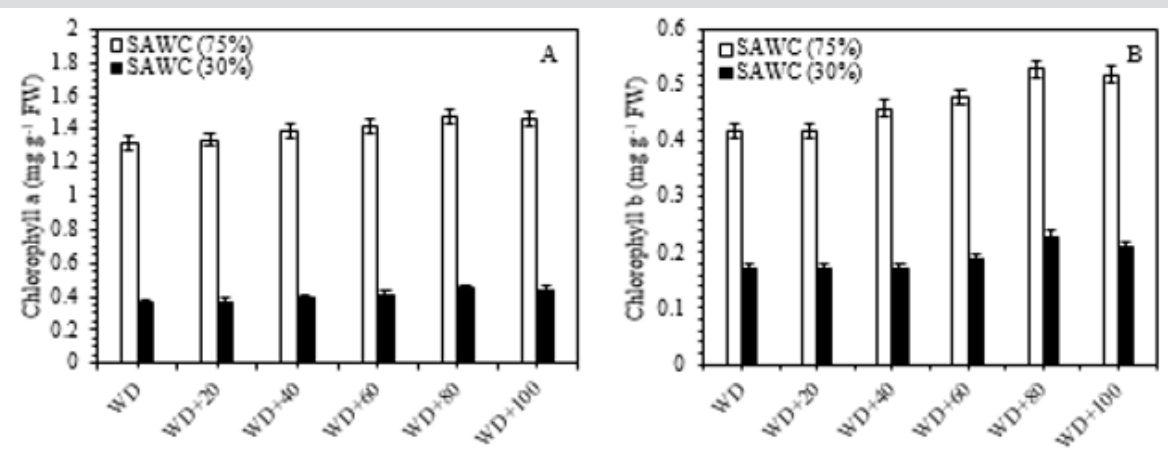

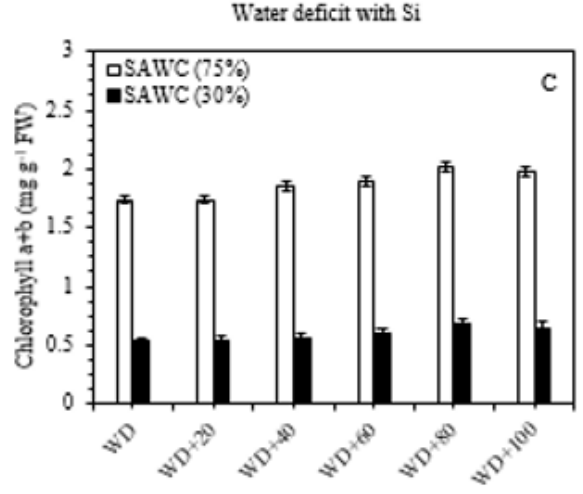

Wizter deficit with Si

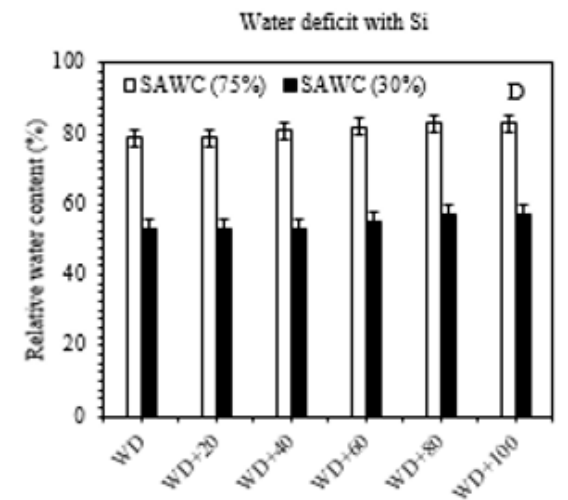

Water deficit with $\mathrm{Si}$

Figure 3: Chlorophyll a (Chl a; A), chlorophyll b (Chl b; B), total chlorophyll $(\mathrm{Chl} \mathrm{a+b;C)}$ and relative water content (RWC- \%; D) in the leaves of sugarcane cultivar GT 42 under 75 and 30\% of SAWC at 45-days after water stress with +Si. The values are the means $( \pm$ SEM) of four biological replicates.

However, there was no further pigment promoting effects from increasing silicon levels (80-100g Si pot-1). Relative water content is known as an alternative method of water level in plants, reflecting the metabolic activities in plant tissues Flower et al. [71]. Similar results were found in many plant species under waterstressed conditions Gadallah [18]; Sairam [70-72]. The reduction in RWC could be due to low availability of water in the soil Kaya et al. [32], which are not able to compensate for loss of water by leaf transpiration through a loss of the absorbing surface Gadallah [73]. Catalase, peroxidase and superoxide dismutase enzyme activities. In comparison with 75 and $30 \%$ of SAWC, the activities of catalase [45.32 vs. $39.45(\sim 15 \%) \& 55.29$ vs. 35.43ng g-1FW (56\%)], peroxidase [ 43.61 vs. $42.63(2.30 \%) \& 41.50$ vs. $51.30 \mathrm{ng}$ g-1FW $(\sim 24 \%)]$ and superoxide dismutase [33.40 vs. $23.92(\sim 40 \%) \&$ 29.35 vs. $18.35 \mathrm{U}$ mg-1FW $(\sim 60 \%)]$ were significantly increased in stressed plants with + Si. The up-regulated activities of antioxidant enzymes such as catalase, peroxidase and superoxide dismutase in response to drought-stressed plants has been largely used as an indicator of drought avoidance Apel et al. [74-76] reported the enhanced level of CAT in wheat genotypes under water stress was associated with the increased stress tolerance.

Maximum up-regulated enzyme activities such as CAT, POD and SOD were observed in $80 \mathrm{~g} \mathrm{Si} \mathrm{pot-1}$ amended under water stress conditions (Table 1). CAT, POD and SOD were up-regulated under all silicon $\left(20-100 \mathrm{~g} \mathrm{Si} \mathrm{pot}^{-1}\right)$ levels (Table 1). According to Sairam 
et al. [77], the activities of CAT and POD were highest in severe stress as compare to mild stress in wheat cultivars. CAT, POD and SOD appears to be a more efficient mechanism for maintaining photosynthetic activities in the water stress tolerance varieties. Besides the plant antioxidant defense system against water deficit, silicon can also alleviate oxidative damage in plants Kim et al. [16]. In view of the above findings, $\mathrm{Si}$ application to sugarcane plants resulted in maintaining high photosynthesis, stomatal conductance, leaf transpiration, photosynthetic pigments and antioxidant enzyme activities under water deficit conditions [78-81].

Table 1: Specific activity of catalase (CAT, $\mathrm{ng} \mathrm{g}^{-1}$ fresh weight), peroxidase (POD, $\mathrm{ng} \mathrm{g}^{-1}$ fresh weight) and superoxide dismutase (SOD, $\mathrm{U} \mathrm{mg}^{-1}$ fresh weight) in the leaves of sugarcane cultivar GT 42, under 75 and 30\% of SAWC at 45-days after water stress with $+\mathrm{Si}$. The values are the means of four biological replicates \pm SEM. WD - water deficit.

\begin{tabular}{|c|c|c|c|c|c|c|c|c|c|c|c|c|}
\hline \multirow[b]{2}{*}{ Treatments } & \multicolumn{4}{|c|}{ CAT (ng g ${ }^{-1} \mathbf{F W}$ ) } & \multicolumn{4}{|c|}{ POD $\left(\mathrm{ng} \mathrm{g}^{-1} \mathrm{FW}\right)$} & \multicolumn{4}{|c|}{ SOD (U mg- $\left.{ }^{-1} \mathrm{FW}\right)$} \\
\hline & $\begin{array}{l}75 \% \text { of } \\
\text { SAWC }\end{array}$ & $\begin{array}{c}\text { Increase } \\
(\%)\end{array}$ & $\begin{array}{l}30 \% \text { of } \\
\text { SAWC }\end{array}$ & $\begin{array}{c}\text { Increase } \\
(\%)\end{array}$ & $\begin{array}{l}75 \% \text { of } \\
\text { SAWC }\end{array}$ & $\begin{array}{c}\text { Increase } \\
(\%)\end{array}$ & $\begin{array}{l}30 \% \text { of } \\
\text { SAWC }\end{array}$ & $\begin{array}{c}\text { Increase } \\
(\%)\end{array}$ & $\begin{array}{l}75 \% \text { of } \\
\text { SAWC }\end{array}$ & $\begin{array}{c}\text { Increase } \\
(\%)\end{array}$ & $\begin{array}{l}30 \% \text { of } \\
\text { SAWC }\end{array}$ & $\begin{array}{c}\text { Increase } \\
(\%)\end{array}$ \\
\hline WD & $\begin{array}{l}39.45 \\
\pm 2.11\end{array}$ & - & $\begin{array}{l}35.43 \\
\pm 1.15\end{array}$ & - & $\begin{array}{l}42.63 \\
\pm 1.15\end{array}$ & - & $\begin{array}{c}41.5 \\
\pm 1.18\end{array}$ & - & $\begin{array}{l}23.92 \\
\pm 1.03\end{array}$ & - & $\begin{array}{l}18.35 \\
\pm 0.89\end{array}$ & - \\
\hline$W D+S i 20$ & $\begin{array}{l}48.18 \\
\pm 3.03\end{array}$ & 22.13 & $\begin{array}{l}43.91 \\
\pm 2.07\end{array}$ & 23.93 & $\begin{array}{l}45.82 \\
\pm 2.03\end{array}$ & 7.48 & $\begin{array}{l}47.66 \\
\pm 2.36\end{array}$ & 14.84 & $\begin{array}{l}34.43 \\
\pm 1.98\end{array}$ & 43.94 & $\begin{array}{l}26.97 \\
\pm 1.01\end{array}$ & 46.98 \\
\hline $\mathrm{WD}+\mathrm{Si} 40$ & $\begin{array}{l}54.06 \\
\pm 1.89\end{array}$ & 37.03 & $\begin{array}{l}47.43 \\
\pm 2.11\end{array}$ & 33.87 & $\begin{array}{l}54.25 \\
\pm 3.32\end{array}$ & 27.26 & $\begin{array}{l}51.67 \\
\pm 2.63\end{array}$ & 24.51 & $\begin{array}{c}33.5 \\
\pm 2.18\end{array}$ & 40.05 & $\begin{array}{l}29.27 \\
\pm 1.19\end{array}$ & 59.51 \\
\hline WD+Si60 & $\begin{array}{l}52.12 \\
\pm 2.87\end{array}$ & 32.12 & $\begin{array}{l}62.80 \\
\pm 3.02\end{array}$ & 77.25 & $\begin{array}{l}55.09 \\
\pm 2.09\end{array}$ & 29.23 & $\begin{array}{l}49.94 \\
\pm 1.89\end{array}$ & 20.34 & $\begin{array}{l}31.88 \\
\pm 1.17\end{array}$ & 33.28 & $\begin{array}{l}33.15 \\
\pm 2.04\end{array}$ & 80.65 \\
\hline $\mathrm{WD}+\mathrm{Si} 80$ & $\begin{array}{l}61.98 \\
\pm 2.01\end{array}$ & 57.11 & $\begin{array}{l}67.72 \\
\pm 3.11\end{array}$ & 91.14 & $\begin{array}{l}55.70 \\
\pm 2.16\end{array}$ & 30.66 & $\begin{array}{l}51.30 \\
\pm 2.88\end{array}$ & 23.61 & $\begin{array}{l}32.54 \\
\pm 1.63\end{array}$ & 36.04 & $\begin{array}{l}35.97 \\
\pm 1.84\end{array}$ & 96.02 \\
\hline$W D+S i 100$ & $\begin{array}{l}45.32 \\
\pm 1.67\end{array}$ & 14.88 & $\begin{array}{l}55.29 \\
\pm 2.31\end{array}$ & 56.05 & $\begin{array}{l}43.61 \\
\pm 1.51\end{array}$ & 2.30 & $\begin{array}{l}32.64 \\
\pm 1.31\end{array}$ & -21.35 & $\begin{array}{c}33.4 \\
\pm 1.09\end{array}$ & 39.63 & $\begin{array}{l}29.35 \\
\pm 1.13\end{array}$ & 59.95 \\
\hline
\end{tabular}

\section{Acknowledgement}

We wish to warmly thank Guangxi Academy of Agricultural Sciences (GXAAS), Nanning, Guangxi, China for providing the necessary facilities for this study. This study was supported in part by the Guangxi Research and Development Program Fund (GK17195100), Fund for Guangxi Innovation Teams of Modern Agriculture Technology (gjnytxgxcxtd-03-01) and Fund of GXAAS (2015YT02).

\section{References}

1. Coskun D, Deshmukh R, Sonah H, Menzies JG, Reynolds O, et al. (2019) The controversies of silicon's role in plant biology. New Phytol 221(1): 67-85.

2. Hodson MJ, Evans DE (1995) Aluminum-silicon interactions in higher plants. J Exp Bot 46(283): 161-171.

3. Epstein E (1999) Silicon. Ann Rev Plant Physiol Plant Mol Biol 50: 641664.

4. Ma J (2004) Role of silicon in enhancing the resistance of plants to biotic and biotic stresses. Soil Sci Plant Nutr 50: 11-18.

5. Liang YC, Chen Q Liu Q Zhang WH, Ding RX (2003) Exogenous silicon (Si) increases antioxidant enzyme activity and reduces lipid peroxidation in roots of salt-stressed barley (Hordeum vulgare L.). J Plant Physiol 160(10): 1157-1164.

6. Liang Y, Si J, Römheld V (2005) Silicon uptake and transport is an active process in Cucumis sativus. New Phytol 167(3): 797-804.

7. Sonobe K, Hattori T, An P, Tsuji W, Eneji AE, et al. (2011) Effect of silicon application on sorghum root responses to water stress. J Plant Nutr 34: 71-82.

8. Kaya C, Tuna L, Higgs D (2006) Effects of silicon on plant growth and mineral nutrition of maize grown under water stress conditions. J Plant Nutr 29(8): 1469-1480.

9. Gong HJ, Chen KM, Zhao ZG, Chen GC, Zhou WJ (2008) Effects of silicon on defense of wheat against oxidative stress under drought at different developmental stages. Biol Plant 52(3): 592-596.
10. Gong HJ, Zhu X, Chen K, Wang S, Zhang C (2005) Silicon alleviates oxidative damage of wheat plants in pots under drought. Plant Sci 169(2): 313-321

11. Ma JF, Takahashi E (2002) Soil, fertilizer, and plant silicon research in Japan. Amsterdam, Netherlands: Elsevier.

12. Guntzer F (2011) Benefits of plant silicon for crops: a review. Agron Sustain Dev 32(1): 201-213.

13. Shen XF, Zhou YY, Duan LS, Li ZH, Eneji AE, et al. (2010) Silicon effects on photosynthesis and antioxidant parameters of soybean seedlings under drought and ultraviolet-B radiation. J Plant Physiol 167(15): 1248-1252.

14. Savant NK, Snyder GH, Datnoff LE (1997) Silicon management and sustainable rice production. Adv Agro 58: 151-199.

15. Kim YH, Khan AL, Waqas M, Jeong HJ, Kim DH, et al. (2014) Regulation of jasmonic acid biosynthesis by silicon application during physical injury to Oryza sativa L. J Plant Res 127(4): 525-532.

16. Muneer S, Park YG, Kim S, Jeong BR (2017) Foliar or subirrigation silicon supply mitigates high temperature stress in strawberry by maintaining photosynthetic and stress-responsive proteins. J Plant Growth Reg 36(2): 836-845

17. Fleck AT, Nye T, Repenning C, Stahl F, Zahn M, et al. (2011) Silicon enhances suberization and lignification in roots of rice (Oryza sativa). J Exp Bot 62(6): 2001-2011.

18. Flam Shepherd R, Huynh WQ, Coskun D, Hamam AM, Britto DT, et al. (2018) Membrane fluxes, bypass flows, and sodium stress in rice: the influence of silicon. J Exp Bot 69(7): 1679-1692.

19. Liu P, Yin L, Deng X, Wang S, Tanaka K, Zhang S (2014) Aquaporinmediated increase in root hydraulic conductance is involved in siliconinduced improved root water uptake under osmotic stress in Sorghum bicolor L. J Exp Bot 65(17): 4747-4756.

20. Pavlovic J, Samardzic J, Kostic L, Laursen KH, Natic M, et al. (2016) Silicon enhances leaf remobilization of iron in cucumber under limited iron conditions. Ann Bot 118(2): 271-280.

21. Kostic L, Nikolic N, Bosnic D, Samardzic J, Nikolic M (2017) Silicon increases phosphorus (P) uptake by wheat under low P acid soil conditions. Plant Soil 419(1-2): 447-455. 
22. Chen DQ, Cao BB, Qi LY, Yin LN, Wang SW, et al. (2016) Siliconmoderated K-deficiency-induced leaf chlorosis by decreasing putrescine accumulation in sorghum. Ann Bot 118(2): 305-315.

23. Che J, Yamaji N, Shao JF, Ma JF, Shen RF (2016) Silicon decreases both uptake and root-to-shoot translocation of manganese in rice. J Exp Bot 67(5): 1535-1544.

24. Sanglard L, Martins SCV, Detmann KC, Silva PEM, Lavinsky AO, et al. (2014) Silicon nutrition alleviates the negative impacts of arsenic on the photosynthetic apparatus of rice leaves: an analysis of the key limitations of photosynthesis. Physiol Plant 152(2): 355-366.

25. Wang YX, Stass A, Horst WJ (2004) Apoplastic binding of aluminum is involved in silicon-induced amelioration of aluminum toxicity in maize. Plant Physiol 136(3): 3762-3770.

26. Mateos Naranjo E, Galle A, Florez Sarasa I, Perdomo JA, Galmes J, et al. (2015) Assessment of the role of silicon in the Cu-tolerance of the $\mathrm{C}_{4}$ grass Spartina densiflora. J Plant Physiol 178: 74-83.

27. Glick BR (2014) Bacteria with ACC deaminase can promote plant growth and help to feed the world. Microbiol Res 169(1): 30-39.

28. Veatch Blohm ME (2007) Principles of plant genetics and breeding. Crop Sci 47: 1763-1763.

29. Dinh TH, Watanabe K, Takaragawa H, Nakabaru M, Kawamitsu Y (2017) Photosynthetic response and nitrogen use efficiency of sugarcane under drought stress conditions with different nitrogen application levels. Plant Prod Sci 20: 412-422.

30. Jangpromma N, Songrsi P, Thammasiririak S, Jaisil P (2010) Rapid assessment of chlorophyll content in sugarcane using a SPAD chlorophyl meter across different water stress conditions. Asian J Plant Sci 9(6): 368-374.

31. Graca JP, Rodrigues FA, Farias JRB, Oliveira MCN, Hoffmann Campo CB, et al. (2010) Physiological parameters in sugarcane cultivars submitted to water deficit. Braz J Plant Physiol 22(3): 189-197.

32. Barbosa AM, Guidorizi KA, Catuchi TA, Marques TA, Ribeiro RV, et al. (2015) Biomass and bioenergy portioning of sugarcane plants under water deficit. Acta Physiol Plant 37: 137-142.

33. Ramesh P (2000) Sugarcane breeding institute, Coimbatore, India effect of different levels of drought during the formative phase on growth parameters and its relationship with dry matter accumulation in sugarcane. J Agro Crop Sci 185: 83-89.

34. Zhao D, Li Y (2015) Climate change and sugarcane production: potential impact and mitigation strategies. Int J Agro.

35. Inman Bamber NG, Bonnett GD, Spillman MF, Hewitt ML, Jackson (2008) Increasing sucrose accumulation in sugarcane by manipulating leaf extension and photosynthesis with irrigation. Aust J Agric Res 59(1): 13-26.

36. Wilkinson S, Davies WJ (2010) Drought ozone ABA and ethylene: new insights from cell to plant community. Plant Cell Environ 33(4): 510-525.

37. Moore JW (2000) Sugar and the Expansion of the Early Modern WorldEconomy: Commodity Frontiers, Ecological Transformation and Industrialization. Review (Fernand Braudel Center) 23: 409-433.

38. Goldemberg J (2008) The Brazilian biofuels industry. Biotech Biofuels 1(1): 6 .

39. Bassi B, Menossi M, Mattiello L (2018) Nitrogen supply influences photosynthesis establishment along the sugarcane leaf. Sci Reports 8 : 2327

40. Dias MOS, Marcelo P Cunha, Charles DF Jesus, George JM Rocha, José Geraldo C Pradella, et al. (2011) Second generation ethanol in Brazil: Can it compete with electricity production? Bioresource Tech 102(19): 8964-8971.

41. Pereira SC, Maehara L, Machado CMM, Farinas CS (2015) 2G ethanol from the whole sugarcane lignocellulosic biomass. Biotech Biofuels 8 : 44
42. Moore PH (1995) Temporal and Spatial Regulation of Sucrose Accumulation in the Sugarcane Stem. Funct Plant Biol 22: 661-679.

43. Coombs J (1984) Sugarcane as an energy crop. Biotech Genetic Eng Rev 1(1): 311-346.

44. Nelson DW, Sommers LE (1996) Total carbon, organic carbon and organic matter. In: Sparks DL et al. (Eds.), Methods of soil analysis. Part 3, Chemical methods. Soil Sci Soc Am Book Ser 5, SSSA, Madison.

45. Olsen R, Cole CV, Watanabe FS, Dean LA (1954) Estimation of available phosphorus in soil by extraction with sodium bicarbonate. Washington, DC US Dept of Agriculture p. 18-19

46. Haby VA, Russelle MP, Skogley EO (1990) Testing soil for potassium, calcium and magnesium. In: Westerman RL (Eds.), Soil testing and plant analysis ( $3^{\text {rd }}$ Edn.), Soil Sci Am, Madison pp. 181-227.

47. Gee GW, Or D (2002) Particle-size analysis. In: Dane JH, Topp GC (Eds.), Methods of soil analysis. Part 4. Physical methods. Soil Sci Soc Am Book Ser 5, Madison 5(11): 255-293.

48. Lindsay WL, Norvell WA (1978) Development of a DTPA test for zine, iron, manganese and copper. Soil Sci Soc Am J 42(3): 421-428.

49. Yamasaki S, Dillenburg LR (1999) Measurements of leaf relative water content in Araucaria angustifolia. Rev Brasilian Fisiologia Vegetal 11: $69-75$

50. Aebi H (1984) Catalase in vitro. Method Enzym 105:121-126.

51. Maehly AC, Chance B (1954) The assay of catalase and peroxidase. D. Glick (Eds.), Methods of Biochemical Analysis 1: 357-425.

52. Klapheck S, Zimmer I, Cosse H (1990) Scavenging of hydrogen peroxide in the endosperm of Ricinus communis by ascorbate peroxidase. Plant Cell Physiol 31(7): 1005-1013.

53. Giannopolitis CN, Ries SK (1977) Superoxide dismutases: I. Occurrence in higher plants. Plant Physiol 59(2): 309-314.

54. Passioura J (2007) The drought environment: physical, biological and agricultural perspectives. J Exp Bot 58(2): 113-117.

55. Zhu Y, Gong H (2014) Beneficial effects of silicon on salt and drought tolerance in plants. Agron Sust Dev 34(2): 455-472.

56. Rizwan M, Ali S, Ibrahim M, Farid M, Adrees M, et al. (2015) Mechanisms of silicon-mediated alleviation of drought and salt stress in plants: a review. Environ Sci Poll Res 22(20): 15416-15431.

57. Epstein E (1994) The anomaly of silicon in plant biology. Proc Nat Acad Sci 91(1): 11-17.

58. Liang YC (1999) Effects of silicon on enzyme activity and sodium, potassium and calcium concentration in barley under salt stress. Plant Soil 209: 217-224.

59. Ma JF, Miyake Y, Takahashi E (2001) Silicon as a beneficial element for crop plants. Studies Plant Sci 8: 17-39.

60. Sage RF (2002) Variation in the $\mathrm{k}$ (cat) of Rubisco in C(3) and C(4) plants and some implications for photosynthetic performance at high and low temperature. J Exp Bot 53(369): 609-620.

61. Vu JCV, Allen LH, Gesch RW (2006) Up regulation of photosynthesis and sucrose metabolism enzymes in young expanding leaves of sugarcane under elevated growth $\mathrm{CO}_{2}$ Plant Sci 171(1): 123-131.

62. Koonjah SS (2006) A quantitative study of water stress effect on sugarcane photosynthesis. Proc S Afr Sug Technol Ass 80: 148-158.

63. De Souza AP, Gaspar M, Da Silva EA, Ulian EC, Waclawovsky AJ, et al. (2008) Elevated $\mathrm{CO}_{2}$ increases photosynthesis, biomass and productivity, and modifies gene expression in sugarcane. Plant Cell Environ 31(8): 1116-1127.

64. Du Y, Nose A, Kondo A, Wasano K (2015) Diurnal Changes in Photosynthesis in Sugarcane Leaves: I. Carbon dioxide exchange rate, photosynthetic enzyme activities and metabolite levels relating to the $\mathrm{C}$ pathway and the Calvin cycle. Plant Production Science 3(1): 3-8. 
65. Mc Cormick AJ, Cramer MD, Watt DA (2006) Sink strength regulates photosynthesis in sugarcane. New Phytol 171(4): 759-770.

66. Sabater B, Rodriquez MI (1978) Control of chlorophyll degradation indetached leaves of barley and oat through effect of kinetin on chlorophyllase levels. Physiol Plant 43: 274-276.

67. Yasseen BT (1983) An analysis of the effects of salinity on leaf growth in Mexican wheats. PhD diss., University of Leeds.

68. Flower DJ, Ludlow MM (1986) Contribution of osmotic adjustment to the dehydration tolerance of water stressed pigeon pea [Cajanas cajan (L) Milsp] leaves. Plant Cell Environ 9(1): 33-40.

69. Sairam RK (1994) Effect of moisture stress on physiological activities of two contrasting wheat genotypes. Ind J Exp Biol 32: 594-597.

70. Ramanjulu S, Sudhakar C (1997) Drought tolerance is partly related to amino acid accumulation and ammonia assimilation: A comparative study in two mulberry genotypes differing in drought sensitivity. J Plant Physiol 150: 345-350.

71. Li C, Nong Q Solanki MK, Liang Q Xie J, et al. (2016) Differential expression profiles and pathways of genes in sugarcane leaf at elongation stage in response to drought stress. Sci Reports 6: 25698.

72. Gadallah MAA (2000) Effects of indole-3-acetic acid and zinc on the growth, osmotic potential and soluble carbon and nitrogen components of soybean plants growing under water deficit. J Arid Environ 44(4): 451-467.

73. Apel K, Hirt H (2004) Reactive oxygen species: metabolism, oxidative stress, and signal transduction. Ann Rev Plant Biol 55: 373-399.

\section{ISSN: 2574-1241}

DOI: 10.26717/BJSTR.2019.15.002685

Yang-Rui Li. Biomed J Sci \& Tech Res

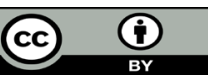

This work is licensed under Creative Commons Attribution 4.0 License

Submission Link: https://biomedres.us/submit-manuscript.php
74. Vilela RD, Bezerra BKL, Froehlich A, Endres L (2017) Antioxidant system is essential to increase drought tolerance of sugarcane. Ann Appl Biol 171(3): 451-463.

75. Osipova S, Permyakov A, Permyakova M, Pshenichnikova T, Börner A (2011) Leaf dehydroascorbate reductase and catalase activity is associated with soil drought tolerance in bread wheat. Acta Physiol Plant 33: 2169-2177.

76. Sairam RK, Deshmukh PS, Saxena DC (1998) Role of antioxidant systems in wheat genotypes tolerance to water stress. Biol Plant 41: 387-394.

77. Gadallah MAA (1995) Effects of water stress, abscisic acid and proline on cotton plants. J Arid Environ 30(3): 315-325.

78. Kim YH, Khan AL, Waqas M, Lee I-J (2017) Silicon regulates antioxidant activities of crop plants under abiotic-induced oxidative stress: a review. Front Plant Sci 8: 510

79. Linag Y, Sun W, Zhu YG, Christie P (2007) Mechanisms of silicon mediated alleviation of abiotic stresses in higher plants: A review. Environ Poll 147(2): 422-428.

80. Shao JF, Che J, Yamaji N, Shen RF, Ma JF, et al. (2017) Silicon reduces cadmium accumulation by suppressing expression of transporter genes involved in cadmium uptake and translocation in rice. J Exp Bot 68(20): 5641-5651.

81. Strain HH, Svec WA (1966) Extraction separation,estimation and isolation of chlorophylls. In The chlorophylls, Vernon LP, Seely GR (Eds.), Academic Press, New York, USA, p. 21-66.

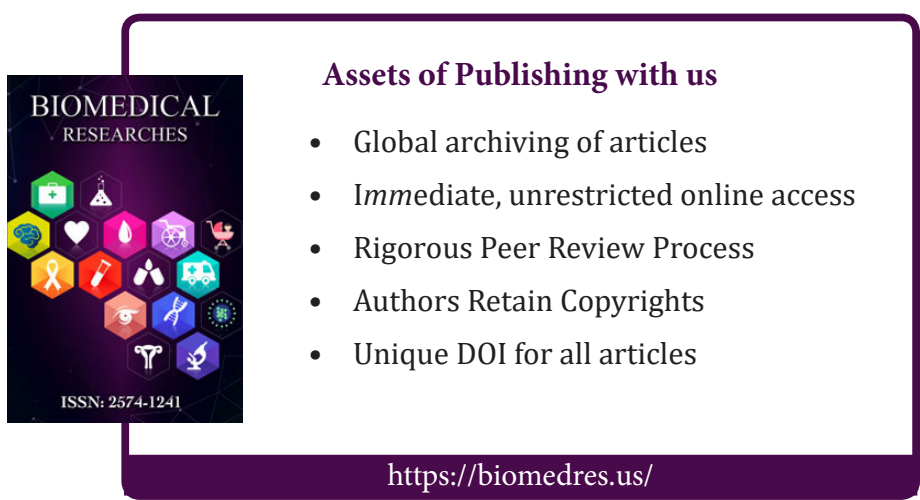

